\title{
On the Periphery in Two Ways: the Sexuality of 'Highly Religious' Protestant Singles in between a Secular Society and Their Religious Context
}

\author{
Tobias Künkler \\ CVJM-Hochschule
}

\begin{abstract}
This paper is based on specific interpretation of the results from a triangulated, empirical study on Protestant and mostly 'highly religious' singles. It demonstrates that 'highly religious' Protestant singles in Germany are on the periphery in two ways. Firstly, they are 'highly religious' individuals in a secular society and secondly, they are singles in a couple society. Furthermore, they are a minority in the context of their 'highly religious' groups not only in terms of numbers, but also in terms of deviation from the conservative norms of family and partnership. This double deviation is most evident in the area of sexuality - hence the focus of this paper are descriptive findings concerning the sexuality of Protestant-Christian singles.
\end{abstract}

\section{Keywords}

Singles; Religious singles; Sexuality; Highly-religious; Deviation

\section{Contact Address}

Prof. Dr. Tobias Künkler, Hugo-Preuß-Straße 40, 34131 Kassel, Germany, kuenkler@cvjm-hochschule.de

"I am convinced that on the one hand most Christians are strangely and sickly marked by a centuries old tradition of rejecting the body. And on the other hand, we are shaped by society as if we could do anything and there is nothing wrong with the way we treat ourselves." Viola

\section{Introduction}

This paper will focus on 'highly religious' Protestant singles in Germany. I argue that this group is on the periphery in two ways. Firstly, they are 'highly religious' individuals in a secular society and secondly, they are singles. This means that they are a minority in the context of their 'highly religious' groups not only in terms of numbers but also in terms 
of deviation from the conservative norms of family and partnership. This double deviation is most evident in the area of sexuality - hence the focus of this paper which is based on an empirical study on religious singles (Protestant and mostly 'highly religious' in terms of centrality of religion according to the CRS-Index). The main topics of the study are everyday life, church life, life satisfaction, dating and sexuality. In our study, we confirmed not only that religious singles "found themselves torn between their religious values and those of secular mainstream young adult society", as Engelberg ${ }^{1}$ showed, but also that they are torn between the conservative norms of their religious contexts and the lives that they are actually living.

\section{Theory}

\section{II.1 Definition of the Central Terms}

What is meant by single? In many research studies, being single is understood primarily as living alone. Statistically, this manifests as a one-person household. In our research the Empirica Single-Study - a single is (similar to Jaeggi and Baas et al.) ${ }^{2}$ someone who, according to his or her own statements, does not have a permanent partnership and has to organize their everyday life alone. ${ }^{3}$

The term 'highly religious' refers to Huber's understanding of religiosity as a personal construct system which influences a person's experience and behaviour and depends on two parameters: centrality and content. ${ }^{4}$ The strength of the influence results from the centrality of the religious construct system, that is the hierarchical status in the set of construct systems of a person. The higher the degree of centrality, the greater the significance compared to other construct systems and the less a construct system is limited in

\footnotetext{
${ }^{1}$ Arie Engelberg, "Update: Singles in Late-Modern Conservative Religions," Journal for the Scientific Study of Religion (ISSR) 55, no. 3 (2016): 652.

${ }^{2}$ Eva Jaeggi, Ich sag' mir selber Guten Morgen: Single - eine moderne Lebensform (München: Piper, 1992), 15. Stephan Baas, Marina Schmitt, and Hans-Werner Wahl, Singles im mittleren und höheren Erwachsenenalter. Sozialwissenschaftliche und psychologische Befunde (Stuttgart: Kohlhammer, 2008), 27.

${ }^{3}$ Although there are other definitions of 'single', for instance only those who are not married or only those who live alone, the Empirica Single Survey was interested in what being single as being without a partnership means. This definition does include people who were formerly married (divorced or widowed), singles who have children and adult singles of a wide range of age. Therefore, by this definition being single holds a heterogeneous range of possible life-circumstances. For more details on the concept of single, various definitions and the debates about it, see Annegret Reese, "Ich weiß nicht, wo da Religion anfängt und aufhört: Eine empirische Studie zum Zusammenhang von Lebenswelt und Religiosität bei Singlefrauen," in Schriftenreihe: Religionspädagogik in pluraler Gesellschaft (RPG) 4, ed. H.-G. Ziebertz, F. Schweizer, R. Englert, and U. Schwab (Gütersloh: Gütersloher Verlagshaus, 2006), 103-107, and Robin Sprenger, Männliche Absolute Beginner: Ein kommunikationswissenschaftlicher Ansatz zur Erklärung von Partnerlosigkeit (Wiesbaden: Springer Verlag, 2014), 29ff.

${ }^{4}$ Stefan Huber, Zentralität und Inhalt: Ein neues multidimensionales Messmodell der Religiosität (Opladen: Leske und Budrich, 2003).
} 
its effectiveness by others. The direction of influence is determined by concrete content. The validity of the centrality scale could be confirmed several times, e.g., on the basis of high correlations with religious self-assessment or with the significance of religion in everyday life. ${ }^{5}$ With the help of the centrality scales and on the basis of threshold values, it is possible to distinguish between highly religious, religious and non-religious persons who differ from one another not only gradually but also qualitatively. ${ }^{6}$ Thus, Huber postulates a 'qualitative leap' between the groups of the 'religious' and the 'highly religious'. In the case of the 'highly religious', religious contents are represented in a more differentiated way and have a stronger influence on general experience and behaviour than in the case of the 'religious'. In 2007, 23 percent of the population of West Germany was classified as 'highly religious' in the Religion Monitor. ${ }^{8}$

The term 'Protestant' refers to those who associate themselves with mainline Protestant Churches, the Pietistic Fellowship within the mainline Protestant Churches ('Landeskirchliche Gemeinschaft') or one of the many Free Churches in Germany. Whenever Protestant highly religious people are mentioned in the following, it is important to stress that they must not be equated with Evangelicals, Pietists or Fundamentalists, even if there is a high proportion of highly religious among the groups mentioned. ${ }^{9}$ According to data from the Religion Monitor 2007, the proportion of highly religious among Protestants in Germany is about 20 percent. ${ }^{10}$

\section{II.2 Singles in a Couple Society}

Being single is a fairly new development in society and part of the revolutionary change in ways of life since the late twentieth century. Despite this radical change, it is undisputed that the bourgeois nuclear family, in spite of its loss of monopoly, has not lost its normative guiding function and, above all, the so-called dyadic norm or the couple ideal of romantic love and togetherness has remained completely stable. For this reason, as Reese notes, the majority of singles also orient their private lives to this dyadic norm and understand

\footnotetext{
${ }^{5}$ Stefan Huber, and Odilo W. Huber, "The Centrality of Religiosity Scale (CRS)," Religions 3 (2012): 711, 715.

${ }^{6}$ Stefan Huber, "Kerndimensionen, Zentralität und Inhalt: Ein Interdisziplinäres Modell der Religiosität," in Journal für Psychologie 16 (2008), 6.

${ }^{7}$ Stefan Huber, "Are Religious Beliefs Relevant in Daily Life? In Religion inside and Outside Traditional Institutions," in Empirical Studies in Theology, ed. Heinz Streib (Leiden and Boston: Brill, 2007). Huber, "Kerndimensionen".

${ }^{8}$ Stefan Huber, "Religiosität in Deutschland, Österreich und der Schweiz," in Gesundheit-Religion-Spiritualität, ed. Constantin Klein i.a. (Weinheim, 2011), 185.

${ }^{9}$ For example, in an analysis of the Religion Monitor data from 2007, Huber shows that although the centrality scale and the fundamentalism scale show a high correlation $(r=.54)$, 'only' one third of the highly religious can be classified as fundamentalists, see Stefan Huber, "Hochreligiös gleich fundamentalistisch? Eine Einordnung," in Evangelisch Hochreligiöse im Diskurs, ed. Tobias Faix i.a. (Stuttgart: Kohlhammer, 2020), 55. ${ }^{10}$ Huber, "Hochreligiös gleich fundamentalistisch," 56.
} 
their single life as a transitional period. ${ }^{11}$ In terms of society as a whole, there are only a few attempts to permanently practice a way of life beyond a couple relationship. Even if today's debates about polyamory, asexuality and objectophilia, which are partly pushed by the media, suggest otherwise, the double norm of "partnering and parenting" applies. ${ }^{12}$

Hence, the social image of singles is usually at least ambivalent. Since family and partnership continue to represent the cultural and social model, singles are initially always the deviant about whom many stereotypes exist. ${ }^{13}$ On the one hand, deviation from the norm leads to devaluation, but on the other hand it also leads to idealization and revaluation. At least one particular form of being single, which is primarily associated with independence and freedom, is especially idealized in certain social milieus and in the media. Non-singles often project suppressed or unfulfilled desires and hopes on singles. ${ }^{14}$ This often results in a mixture of admiration and rejection. Singles are e.g. the sexually deviant. According to the stereotype, they have an exciting and varied sex life with many sexual partners and are thereby maximally satisfied, non-binding, irresponsible and free - exemplarily for this is probably the one-night stand. This is admired, idealized, critically observed or even despised at the same time. ${ }^{15}$

As Hertel et al. has empirically researched, singles are described as lonely and miserable rather than warm and caring compared to married people. ${ }^{16}$ These ascriptions were independent of the age, sex, or life status of the respondent, so they were also made by singles themselves. According to Hertel, the cultural attitude (guideline for oneself and others) seems to be that one should be married or at least have a partner by the age of $35 .{ }^{17}$ 80 percent of female and 85 percent of male singles have a desire for a partner. ${ }^{18}$ Only

\footnotetext{
${ }^{11}$ Reese, "Ich weiß nicht, wo da Religion anfängt und aufhört," 101.

${ }^{12}$ Elizabeth Addie, and Charlotte Brownlow, "Deficit and Asset Identity Constructions of Single Women without Children Living in Australia: An Analysis of Discourse," Feminism \& Psychology 24, (2014): 424. For more about the history of singles, see Tobias Künkler, Tobias Faix, Johanna Weddigen, Daniel Beckemeier, Marie Jäckel, Simon Merz, and Philipp Funke, "Forschungsbericht zur Empirica Singlestudie 2020," Lebensweisen christlicher Singles (2020): 3-7.

${ }^{13}$ Leonard Cargan, Being Single on Noah's ark (Lenham: Rowman \& Littlefield Publishers, 2007), 54-56.

${ }^{14}$ Stefan Hradil, "Vom Leitbild zum „Leitbild“: Singles, ihre veränderte Wahrnehmung und der „Wandel des Wertewandels"," Zeitschrift für Familienforschung 15 (2003): 44-45.

${ }^{15}$ Roona Simpson, "Singleness and Self-identity. The Significance of Partnership Status in the Narratives of Never-married Women," Journal of Social and Personal Relationships (JSPR) 33, no. 3 (2016): 386. Cargan, Being Single, 58.

${ }^{16}$ Janine Hertel, Astrid Schütz, Bella DePaulo, Wendy L. Morris, and Tanja S. Stucke, "She’s Single, So What? How Are Singles Perceived Compared with People who Are Married?," Zeitschrift für Familienforschung 19, no. 2 (2007).

${ }^{17}$ Hertel et al., "She's Single," $148 \mathrm{ff}$.

${ }^{18}$ Armando Häring, Thomas Klein, Johannes Stauder, and Anke Woll, "Partnermarkt und Suchverhalten von Singles in Deutschland," in Partnerschaft, Fertilität und intergenerationale Beziehungen: Ergebnisse der ersten Welle des Beziehungs-und Familienpanels, ed. J. Brüderl, L. Castiglioni, and N. Schumann (Würzburg: Eragon-Verlag, 2011), 56.
} 
5 percent do not want to lead a stable partnership under any circumstances. ${ }^{19} 84$ percent of singles want to fall in love again, 76 percent strive for a stable love relationship in the future. ${ }^{20}$ Two thirds of the singles are still waiting for the 'great love' in life. ${ }^{21}$ In addition, most singles do not describe their single existence as the result of a decision or choice and describe themselves as involuntarily living without a partner. ${ }^{22}$ All in all, there is a clear picture of singles as deviants in a society characterized by family and partnerships.

\section{II.3 ('Highly') Religious Singles}

Since the 1990s, research on singles has emerged as a research line in its own right and has produced ongoing results, it is still essentially true that there is very little or no information about the religion and religiosity of singles. ${ }^{23}$ In a research overview, which also includes many studies from the Jewish and Muslim context, it becomes clear that religious and especially highly religious singles have a more tense and precarious existence, as they tend to live between worlds and are strongly torn between them. ${ }^{24}$ Engelberg points to a lack of a social script for highly religious singles. ${ }^{25}$ In the words of Smith: "Mainstream culture has more positive models of living a full life as a person who's not married." ${ }^{26}$

Tweed emphasizes that although a slow change in society can be observed with regard to marriage and family norms, religious people in particular believe that one cannot lead a satisfactory life without marriage. ${ }^{27}$ The great importance of the family norm means that many Protestant-Christian singles feel that they are of secondary importance in their church. $^{28}$

According to Smith, there are the following assumptions for Protestant-Christian singles: - God will give everyone a spouse. This is often attributed to singles by parishioners or friends, and single women in particular often hold on to this supposed promise for years. $^{29}$

- It is often suggested that true spiritual growth and joy can only be found in marriage. ${ }^{30}$

${ }^{19}$ Elisabeth Monyk, Lieber alleine oder zu zweit? Die individualistische Lebensweise von Singles und kinderlosen Paaren (Münster, Berlin: LIT Verlag, 2007), 145.

${ }^{20}$ Monyk, Lieber alleine, 142.

${ }^{21}$ Monyk, Lieber alleine, 137.

${ }^{22}$ Simpson, "Singleness and Self-Identity," 392.

${ }^{23}$ Reese, "Ich weiß nicht, wo da Religion anfängt und aufhört," 148. Engelberg, "Update," 625.

${ }^{24}$ Engelberg, "Update," 652.

${ }^{25}$ Engelberg, "Update," 651.

${ }^{26}$ Joy Beth Smith, Party of One: Truth, Longing and the Subtle Art of Singleness (Nashville: Nelson Books, 2018), 66.

${ }^{27}$ Julie Michelle Tweed, “An Examination of Changing Perceptions of Singlehood” (Thesis in partial fulfillment of the requirements for the degree Master of Arts in Sociology Faculty of the Department of Sociology and Anthropology, East Tennessee State University, 2008).

${ }^{28}$ Smith, Party of One, 42.

${ }^{29}$ Smith, Party of One, 11, 5.

${ }^{30}$ Smith, Party of One, 38. Julie Michelle Tweed, "An Examination". 
- Jesus is often considered a substitute for a partner. "So we date Jesus, he romances us, and then we marry him, the handsome groom who relentlessly pursues his beloved". ${ }^{31}$ This could lead to the fact that a Protestant-Christian single should not feel alone or lonely at all, since he or she has Jesus. ${ }^{32}$

- The sexuality of singles is hardly ever discussed in Protestant-Christian communities, as the solution to all sexual needs and problems is always marriage. In many churches, masturbation is also considered a sin. The sexuality of singles can therefore only be a sin. All this leads to the suggestion that singles are not sexual beings and have no sexual needs. ${ }^{33}$

Engelberg also emphasizes the area of sexuality. ${ }^{34}$ Although the studies show that most highly religious singles do not adhere to the sexual-ethical norms of their context, they tend to be more conservative and sexually active later than the average of their peers.

\section{Method}

\section{III.1 Description of Data and Sample}

The main themes of the explorative study are everyday life, church life, life satisfaction, dating and sexuality. The design of the overall study is based on a mixed methods approach, combining quantitative and qualitative methods in one study. Due to the time schedule, it was not possible to complete the qualitative research and use its results as a basis for the quantitative research design or vice versa. However, since the qualitative research process started earlier than the quantitative one, the first qualitative results were used for the questionnaire design.

The qualitative part of the study is based on semi-structured interviews with 14 Protestant singles, selected via a contrastive sample (according to the factors gender, age, place of residence, family status, denomination, education and religious socialization). The data analysis was done with a Grounded Theory - Approach. ${ }^{35}$

In the quantitative online survey, the sample $(\mathrm{n}=3235)$ consisted of singles who view themselves as Christians, ${ }^{36}$ have been without a permanent partnership for at least 2.5 years and are at least 21 years old. It was not possible to draw a random sample with the

\footnotetext{
${ }^{31}$ Smith, Party of One, 48.

32 Smith, Party of One, 45.

33 Smith, Party of One, 94-103.

${ }^{34}$ Engelberg, "Update," 654.

${ }^{35}$ Anselm Strauss and Juliet Corbin, Grounded Theory: Grundlagen Qualitativer Sozialforschung (Wiesbaden: VS Verlag für Sozialwissenschaften, 1996).

${ }^{36}$ This sample only contains Protestant Christians. Christians of the Catholic faith were excluded post-survey because of the small number of Catholic participants $(n=198)$. Reliable statements for Catholic Christians based on the data were not possible. Therefore, this article only refers to Protestant Christian singles.
} 
available resources in the quantitative part of the study. As it is often the case with rare populations, this study uses a so-called convenience sample.

For sampling purposes, attention was drawn to the online survey in several ways. The sample was drawn by specific ways, on which we assumed to reach highly religious, Protestant singles, e.g. online-dating agencies for Christian singles. ${ }^{37}$ For this purpose, not only the field knowledge of some members of the research group was used, but also a number of experts working with highly religious, Protestant singles.

See Table 1 for the descriptive statistics of the sample.

Table 1. Descriptive statistics of the sample.

\begin{tabular}{lcc}
\hline & N $(\%)$ or M (SD) & Min. and Max. \\
\hline Age & $38.11(12.70)$ & $21 / 84$ \\
\hline Gender & $2245(69.63 \%)$ & \\
Female & $979(30.37 \%)$ & \\
Male & & \\
\hline Denomination & $802(24.95 \%)$ & \\
Mainline Protestants & $232(7.22 \%)$ \\
Piet. Fellowship Prot. churches & $2.049(63.75 \%)$ \\
Free churches/others & $131(4.08 \%)$ & \\
No church & & \\
\hline Household type & $1944(60.32 \%)$ & \\
One-person household & $196(6.08 \%)$ \\
Single parent & $243(7.54 \%)$ \\
With family members (only parents/grandparents) & $50(1.55 \%)$ & \\
Extended family (with children and parents) & $716(22.22 \%)$ & \\
Flat-sharing community & $33(1.02 \%)$ & $3 / 64$ \\
Binding community & $41(1.27 \%)$ & \\
Other & $11.71(9.40)$ & \\
\hline How long are they single? (in years) &
\end{tabular}

In terms of age younger people, in terms of denominations the free churches and in terms of gender women are probably ${ }^{38}$ overrepresented in the data. In the data analysis, the central variables were therefore analysed differentiated by age, gender and denomination.

We did, for pragmatic reasons - in order to have more space in the questionnaire for other questions -, not use the complete centrality score that Huber established. We used two key indicators, however, to measure centrality: "How often do you pray?" And: "How often do you attend church services?" Table 2 shows that the respondents of the

${ }^{37}$ For detailed information about the drawing of the sample and the overall research design, see Künkler et al., "Forschungsbericht," 22ff.

38 There is a lack of clear comparative data here, e.g. with regard to gender there is knowledge of a correlation between religiousness and gender (i.e. women are measurably more religious than men) and therefore it can be expected that among highly religious singles the proportion of women is higher. See Jessica L. Collett, and Omar A. Lizardo, "A Power-control Theory of Gender and Religiosity," Journal for the Scientific Study of Religion 48 (2009). 
Empirica Single Survey 2019 pray and attend church services even more frequently than the respondents of the Empirica Youth Survey 2018. ${ }^{39}$ In the latter with a similar sampling strategy, the complete centrality score was measured. The result was that three quarters of the participants $(74.9 \%)$ could be identified as 'highly religious' and 25.1 percent as 'religious'. Accordingly, we can assume that there is at least a similarly high proportion of highly religious in the sample of the Empirica Single Survey. The comparison with the Allbus data shows how much the 'highly religious' Protestant singles differ from the average German population.

Table 2. Religiosity of the sample compared to Empirica Youth Survey 2018* and Allbus 2002/2012

\begin{tabular}{|c|c|c|c|}
\hline & $\begin{array}{c}\text { Empirica Single } \\
\text { Survey } 2019 \\
\text { N (\%) }\end{array}$ & $\begin{array}{c}\text { Empirica Youth } \\
\text { Survey } 2018^{40} \\
\text { N }(\%)\end{array}$ & $\begin{array}{c}\text { Allbus } 2002 \text { (prayer) } \\
\text { and Allbus } 2012 \\
\text { (churchgoing) } \\
\mathrm{N}(\%)\end{array}$ \\
\hline \multicolumn{4}{|l|}{ Frequency of prayer } \\
\hline$>$ Once a day & $2002(62.5 \%)$ & $1367(42.9 \%)$ & 1 \\
\hline Once a day & $553(17.1 \%)$ & $655(20.6 \%)$ & $591(17.0 \%)$ \\
\hline $\begin{array}{l}\text { More than once a week- Once a } \\
\text { week }\end{array}$ & $472(14,5 \%)$ & $713(22.4 \%)$ & $459(13.2 \%)$ \\
\hline $\begin{array}{l}\text { Between once a month and several } \\
\text { times a year }\end{array}$ & $95(3 \%)$ & $301(9.5 \%)$ & $468(13.5 \%)$ \\
\hline Rarely & $42(1.3 \%)$ & $70(2.2 \%)$ & $592(17.0 \%)$ \\
\hline Never & 1 & 1 & $1342(38.6 \%)$ \\
\hline No answer & $51(1.6 \%)$ & $59(1.9 \%)$ & $28(0.8 \%)$ \\
\hline Total & 3235 & 3187 & 3480 \\
\hline \multicolumn{4}{|l|}{ Frequency of churchgoing } \\
\hline > Once a week & $253(7.8 \%)$ & $366(22.5 \%)$ & $71(2.1 \%)$ \\
\hline Once a week & $1560(48.5 \%)$ & $1287(40.4 \%)$ & $205(6.1 \%$ \\
\hline $\begin{array}{l}\text { Between once a month and several } \\
\text { times a year }\end{array}$ & $1234(38.2 \%)$ & $1356(42.5 \%)$ & $931(27.6 \%)$ \\
\hline Rarely & $136(4.2)$ & $87(2.7 \%)$ & $1094(32.46 \%)$ \\
\hline Never & $18(0.6 \%)$ & $6(0.2 \%)$ & $1066(31.6 \%)$ \\
\hline No answer & $25(0.8 \%)$ & $85(2.7 \%)$ & $4(0.1 \%)$ \\
\hline Total & 3235 & 3187 & 3370 \\
\hline
\end{tabular}

*Those who never pray were excluded in the Empirica Surveys.

\footnotetext{
${ }^{39}$ With the only exception of multiple visits to church services in one week, which is arguably special for younger people.

${ }^{40} 1$ Short summary of the Empirica Youth Survey 2018: ( $\left.n=3187\right)$, "highly religious" Protestant adolescents and young adults (from 14 to 29 years), 74.9\% "highly religious", 25.1\% "religious", aim: insight into the lives and beliefs of young, "highly religious" Protestants as well as understanding how this particular group's beliefs are reflected in their everyday life.
} 


\section{III.2 Methods of quantitative data analysis}

With the aim of investigating the extent to which different items or variables measure the same theoretical construct, we made intensive use of principal component analysis in the single study. Due to the rather scarce high-quality data of Protestant-Christian singles, their interests, attitudes, needs and characteristics, many scales were newly formed in this study (Attitudes towards Sexuality, Satisfaction with Sexuality). The questions concerning attitudes towards sexuality (see Table 4), that later formed the scale, were inspired by Wulf et al. ${ }^{41}$ and adjusted for the use of the Empirica study. Questions about satisfaction with sexuality (Table 6) which later formed the satisfaction-scale were inspired by Gaynor and Underwood, Snell, as well as Winter. ${ }^{42}$ The number of components of the scales is determined by the Kaiser criterion, Minap (minimum average partial correlation), Horn's parallel analysis and the scree-test. The quality of the scale is consequently determined by Cronbach's Alpha (see Table 4).

To investigate the correlation between two variables, significance tests with a 99 percent significance level were carried out. Due to the fact that positive significance tests lead to a premature confirmation of a hypothesis, a differentiated significance test was additionally performed to examine groups in a more differentiated way by dividing them into subgroups and then testing whether they differ significantly from the previous one. The correlations reported below are all significant in the above sense.

\section{Results \& Discussion}

Our data show that the majority of the 'highly religious' Protestant singles are in a kind of equidistance to the Christian world within their highly religious context and to the secular world outside of it. When asked: "From the gut: Where do you feel more comfortable as a single?", 51 percent answered "equally well/unwell in both worlds". For the rest, there was a slight tendency towards interior orientation (27 percent felt more comfortable inside and 20 percent outside). This equidistance is clearly shown in many of the results of the Empirica Single-Study, but the area of sexuality will be examined more closely in the following, since here the double tension is particularly evident, as Engelberg (see Part II) had demonstrated. ${ }^{43}$ While in the secular context, as explained above, the cliché of the

\footnotetext{
${ }^{41}$ Jean Wulf, David Prentice, Donna Hansum, Archie Ferrar, and Bernard Spilka, "Religiosity and Sexual Attitudes and Behavior among Evangelical Christian Singles," Review of Religious Research 26, (1984): 119-131. ${ }^{42}$ Pamela A. Gaynor and Julie K. Underwood, "Conceptualizing and Measuring Sexual Self-esteem," in Personality Research, Methods, and Theory, ed. P. E. Shrout and S. T. Fiske (London: Erlbaum, 1995), 333-347. William E. Snell, "The Multidimensional Sexual Self-Concept Questionnaire," in Handbook of Sexualityrelated Measures, ed. C. M. Davis, W. L. Yarber, R. Bauserman, G. E. Schreer, and S. L. Davis (Newbury Park: Sage, 1998), 521-524; Laraine Winter, "The Role of Sexual Self-concept in the Use of Contraceptives," Family Planning Perspectives 20, (1988): 123-127.

${ }^{43}$ Engelberg, "Update".
} 
swinging single exists, in the highly religious context, sexual contacts tend to be considered legitimate only in the context of marriage. ${ }^{44}$

In a first step, we reviewed some of the sexual-ethical attitudes of 'highly religious' Protestant singles. "You should wait until marriage before you have sexual intercourse with your partner". 62 percent of them at least tended to agree with this statement, 45 percent even fully agreed. Similar tendencies showed up in the Empirica Family Study, ${ }^{45}$ which was likewise accomplished with Protestant 'highly religious' test persons. There the vast majority of the Protestant-Christian parents (71\%) wanted their child to wait until marriage before he or she had sex with a partner. In a study from Great Britain, even 77 percent of Protestant-Christian singles stated that sex belongs in marriage. ${ }^{46}$ Of those who agreed, about two-thirds thought it was acceptable, while one-third thought it was difficult to accept and live with. In the qualitative interviews of the Empirica Single-Study, most of the singles also very clearly committed themselves to this norm, e.g. Vera reports that she "very consciously, not out of compulsion" ${ }^{47}$ decided "not to have any extramarital relationships or any one-night stands." She emphasized that she had already been married once and therefore knew what she was giving up. Therefore, it was also clear to her the other way round: "[... if I were not a believer, then I think I would have some one-night stands." Werner saw it very similarly: "Yes, that is what the Bible says and that is how I see it. That applies to me. If I met a woman now, then I would marry her first before I would have sex with her. That's actually quite clear to me." Only a minority of the interviewees contradict here or at least express ambivalences, like Helmuth: "Of course, this is a hot question now. Well, I'll tell you quite honestly, I've read the Bible, I know the Bible, I don't know any sentence that clearly says 'no sex before marriage', that's not in the Bible."

All the statements on attitudes towards sexuality in the quantitative part of the study were combined in a principal component analysis. The criteria for the two scales we used are shown in Table 3.

Table 3. Criteria principal component analysis

\begin{tabular}{lcccccc}
\hline & KMO & $\begin{array}{c}\text { Kaiser- } \\
\text { Criterium }\end{array}$ & Minap & $\begin{array}{c}\text { Horn's- } \\
\text { parallel } \\
\text { analysis }\end{array}$ & $\begin{array}{c}\text { Screetest } \\
\text { Alpha test } \\
\text { scale }\end{array}$ \\
\hline $\begin{array}{l}\text { Scale: Attitudes } \\
\text { towards Sexuality }\end{array}$ & 0.68 & 1 & 1 & 1 & 1 & 0.77 \\
$\begin{array}{l}\text { Scale: Satisfaction } \\
\text { with Sexuality }\end{array}$ & 0.71 & 1 & 1 & 1 & 1 & 0.85 \\
\hline
\end{tabular}

\footnotetext{
${ }^{44}$ Addie, and Brownlow, "Deficit and Asset Identity," 430.

45 Short summary of the Empirica Family Survey 2017: ( $\mathrm{n}=1,752)$, ('highly') religious Christian parents (with at least one child between the age of 4 to 18 living in their home), 77.4\% 'highly religious', aim: insight into the 'religious' parenting of Christian parents, their parenting style, family-and gender norms in 'highly' religious households and what role the Christian faith plays in the upbringing of the parent's children. ${ }^{46}$ Single Friendly Church, the Research, (2020).

${ }^{47}$ Here and in the following, after an own translation of direct quotes from the qualitative interviews, as close as possible to the original wording.
} 
Table 4. Principal component analysis of the dimensions of attitudes towards sexuality

\begin{tabular}{lcc}
\hline Variable & Component 1 & Uniqueness \\
\hline "Sexual daydreams are normal and completely acceptable" & 0.86 & 0.27 \\
"Masturbation is an appropriate way of dealing with sexual needs" & 0.86 & 0.27 \\
"You should wait until marriage before having sexual intercourse with & 0.78 & 0.39 \\
& & \\
\hline
\end{tabular}

The result is that a total of 43 percent of 'highly religious' Protestant singles tend to have conservative sexual ethics, while 27 percent tend towards a liberal attitude and 30 percent are exactly in the middle between the two positions.

Figure 1. Attitudes towards

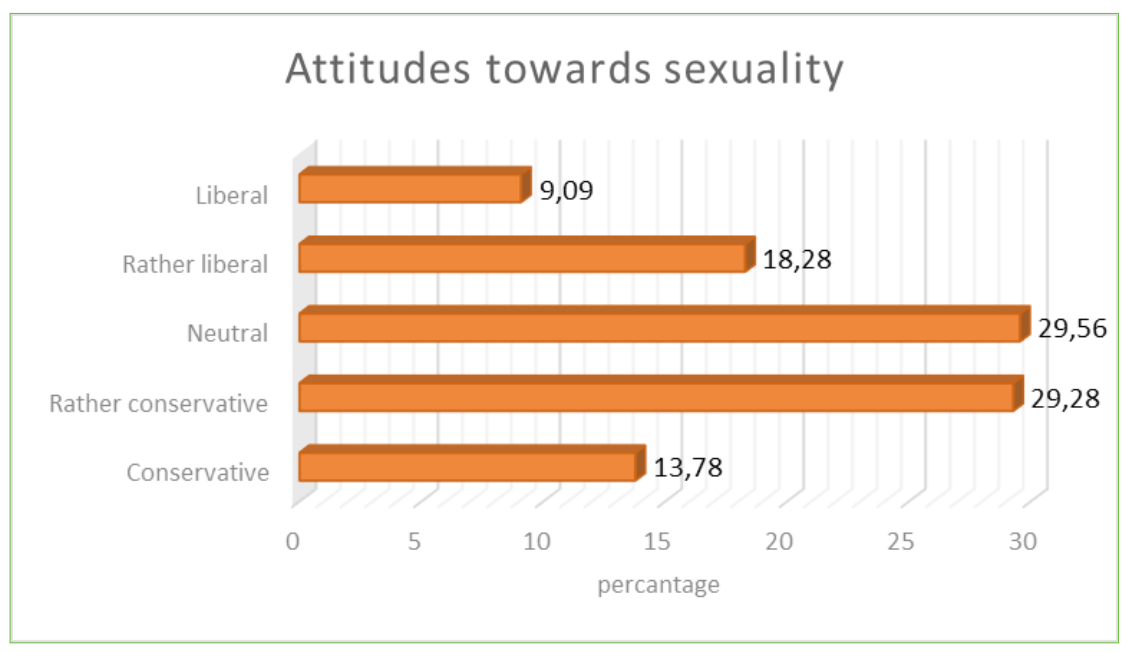

More liberal sexual-ethical attitudes correlate with a higher number of sexual partners. This correlation becomes particularly clear if one examines only those singles who have not yet been married. The singles who already had a partnership were more liberal in their attitudes compared to those who have no partnership experience. The data do not indicate, however, whether it is the experiences that make the attitudes more liberal, or the more liberal attitudes make these experiences more likely. There are in all probability influences from both directions.

What is the general picture of the sexual experiences of 'highly religious' Protestant singles? Looking at the number of sexual partners*, it is 2.3 for men and 1.9 for women. Nine percent of the 'highly religious' Protestant singles have had six or more sexual partners. If you consider only the singles who have never been married, two thirds of them have never had a sexual partner. These are astonishing numbers. According to recent data from the USA, 82 percent of Evangelical men and 86 percent of Evangelical women who are adults and have never been married have had at least one sexual partner*. ${ }^{48}$ If one consid-

48 Single Friendly Church, the Research. 
ers, however, only those who attend a weekly church service and at the same time say that their faith is very important in their everyday life (both indicators of high religiousness), then among the Evangelical youth there is also 'only' 33 percent who have some form of sexual intercourse without being married. If one compares our results on sexual partners* with the data on the ethical attitude towards the norm 'no sex outside marriage', one might initially think that the discrepancies between attitude and practice are not as large, since, as mentioned earlier, about one third of the singles who have never been married do not comply with the norm 'no sex outside marriage' and about $20 \%$ of all those questioned also disagree with this norm.

Table 5. Number of sexual partners* for people who already have been in a relationship

\begin{tabular}{lccccc}
\hline \multicolumn{5}{c}{ number of sexual partners* } \\
\hline $\begin{array}{l}\text { People who } \\
\text {...(in percentage) }\end{array}$ & 0 & 1 & $2-3$ & $4-6$ & $>6$ \\
$\begin{array}{l}\text {..have never been married } \\
\text { (but have been in a relationship) }\end{array}$ & 40.4 & 16.1 & 17.3 & 10.6 & 15.7 \\
$\ldots$...have been married & 1.5 & 22.6 & 28.2 & 24.1 & 23.6 \\
\hline
\end{tabular}

A closer look reveals two things. On the one hand, three quarters (76\%) of the singles who have already been married had two or more sexual partners*. Twenty-four percent had six or more. Even if one assumes that some of them were married several times, it is clear that a large majority of them had sexual intercourse not only with their former (divorced or deceased) partners* but also outside of marriage. Looking at the singles who have never been married but have had a stable partnership, 'only' 40 percent of them have never had a sexual partner. On the other hand, 60 percent of those have had at least one sexual partner*, 44 percent have had two or more. If one excludes sexual services and one-night stands, it becomes clear. Of those who had a clear opportunity not to adhere to the norm 'no sex outside of marriage', it is only a minority who still adhere to this norm. In addition, the small number of those with only one sexual partner* in both groups mentioned (23 percent of those who have already been married, 16 percent of those who have had partnership experience) indicates that there is a clear trend. Those who fail to comply with the norm once will probably fail to do so more often in the future. This tendency is also evident in current data on the sexual behaviour of Evangelical US teenagers. ${ }^{49}$

A correlation between prayer and sexual intercourse could be measured. About three percent of singles who pray more than once a day have sexual intercourse several times a year. For singles who pray less than once a day, this already applies to ten percent. There are similar tendencies with masturbation. There is also a clear correlation between prayer and the number of sexual partners. Those who pray more than once a day have an average of 1.8 sexual partners*, those who pray less than once a week have twice as many: 3.6. Seventy percent of singles who pray more than once a week have had no sexual partner*,

${ }^{49}$ Single Friendly Church, the Research. 
only six percent have had more than six partners*. On the other hand, 44 percent of singles who pray less than once a week have not had a sexual partner, and just under a fifth of them (19\%) have had more than six sexual partners. There is a similar correlation with regard to the frequency of attending church services. The following in all probability applies here: the more religious (prayer and service attendance), the more conservative the sexual ethics and the less the sexual experience. Singles with clearly conservative sexual ethics had an average of 0.8 sexual partners*, while those with a clearly liberal attitude had 5.5. Despite all the divergences and discrepancies between sexual ethics and practice, there is also a clear connection between the two. Nevertheless, sexual-ethical attitudes and sexual practices diverge in almost every respect.

How do 'highly religious' Protestant singles deal with the tension? The qualitative results show the spectrum. At least for a few, tension does not seem to exist, everything is, in their view, a question of decision and habituation. Elisabeth believes:

[...] that if one cannot live out sexuality in the form prescribed by the Bible, i.e. in a marriage between a man and a woman, then one is better off abstinent - or ... What is the right word? Asexual or whatever ... -, abstinent, right now it occurs to me, that I can live and that this is not a problem. Well, I think that we humans are all able to control ourselves or at least we should be able to control ourselves, and in this respect I think that ideally one should follow the guidelines of the Bible or otherwise just do without.

Peter also reacts to the question about how to deal with his sexual needs as follows:

Hm, how do I deal with it? I just live abstinent. I can say no more about this. Well, I don't drink alcohol, for example, so I don't have to have everything in life. I've got used to that, let's say.

Other interviewees report a strong struggle, for example Vera:

But I decided to do it - and sometimes the longing is stronger, sometimes it is not so strong. As I grow older, the longing is not as strong as it was, which is also quite good. But of course, I also know other phases in which I was sometimes tempted to say 'Oh come on, I'm going to grab someone here now', just to experience sex again. But I never put that into practice, I'm glad because I said 'I have to do without other things'. I can't always take a free ride. [...] It's good if you learn that in life as well, to consciously renounce things as well as other things. I don't always have to live this out, but can also consciously say: 'I don't want that, I just want to be obedient to God. [...] I don't know if I will manage to do this until the end of my life, but I am glad and thankful that I never had any experiences like this that I would regret in retrospect. 
Anna, on the other hand, believes that "people are simply sexual beings" and that it is "not manageable" to "limit this to a partnership". She also expresses the impression that "people who take this very seriously, tend to be screwed up", they "cut off their sexuality", which reminds her of a kind of "Muslim full veil". For herself, on the one hand, masturbation, as mentioned above, is not taboo:

And on the other hand, there are always men in my life with whom I can experience closeness, also erotic closeness. But on a level that I can now account for from my faith. [...] And that is very important for me. Well, I think if it didn't exist, I think I would miss it much more than I do now. And otherwise, otherwise there are always longings in my life that are not satisfied and where I am also unhappy about it.

Nina speaks quite explicitly about the suppression of her sexual needs. When asked about how to deal with her sexual needs, she says:

I would say, part of them I certainly suppress. I am studying for psychotherapy. There is a defence mechanism that I think is called sublimation, which means shifting the energy to something else. I just put more energy into other things.

Marie has 'come to terms' with not having intercourse. When asked about how to deal with her sexual needs, she answers:

Hm (pause) repress, push away ... No! (laughs) Partially. I have the great fortune that already I'm a little older and sometimes some medications that are useful help to dampen the whole thing a little bit, so that I hardly have any problems. So that ..., it offers itself..., well, there is actually no big problem.

However, it is "difficult for her to be in a mixed sauna". While in many interviews with the female singles the tension is the main topic and you can feel it even more intensely between the lines, the men tend to talk more about the model 'tension removal'. Ralf says: "Men are simply so that they have emptied themselves at some point or another". For Helmuth it was very important "not to commit adultery", "not to commit spiritual adultery, that means also no porn", at least as long as he was still married "on paper, that means also including the year of separation".

Already in this phase one had to have one's seven senses, one's brain, not only in the lower half of the body, but a little bit further up. After that, [...], well, if I'm honest, then you watch porn or take matters into your own hands. That was already the case.

How do the tensions clearly shown in the results affect the satisfaction of ProtestantChristian singles with their sexuality? "I can enjoy sexuality without feeling guilty." In 
relation to this statement, the singles were quite undecided. Thirty-five percent agreed, thirty-six did not. On the other hand, there was a clear tendency to disagree ( $47 \%$ to $29 \%$ ) regarding the statement: "I like the way I handle my sex life." The clearest and with very similar figures was also the rejection of the statements "I am satisfied with the quality of my sex life" and "Compared to most other people, my sex life is satisfactory". Here 55 percent and 53 percent did not agree and only 16 percent and 14 percent agreed.

Table 6. Principal component analysis of the dimensions of satisfaction with sexuality

\begin{tabular}{lcc}
\hline Variable & Component 1 & Uniqueness \\
\hline "Compared to most other people, my sex life is satisfactory" & 0.89 & 0.20 \\
"I am satisfied with the way I handle my sex life" & 0.83 & 0.31 \\
"I am satisfied with the quality of my sex life" & 0.91 & 0.17 \\
\hline
\end{tabular}

If these results are summarized in a principal component analysis, it becomes apparent that almost three quarters of Protestant-Christian singles (72\%) tend to be dissatisfied with their sexuality. More than a third of them were even quite clearly so, whereas only just under nine percent of the singles were satisfied. This is certainly, on the one hand, due to the fact that for many of the interviewees their basic needs were not satisfied, but on the other hand also because of the fact that for many of them the satisfaction of their needs was a violation of their convictions or at least those of their environment - which is shown among other things by the fact that only a third of them could enjoy their own sexuality without feeling guilty. Statistical correlations could also be shown between satisfaction with one's own sexuality and the strength of the tension (from the deviation between practice and attitude). Particularly with regard to sexual fantasies and masturbation, there were clear deviations from attitude and practice. It was also shown that the more liberal the sexual-ethical attitudes towards sexuality were, the more sexuality could be enjoyed

Figure 2. Satisfaction with sexuality

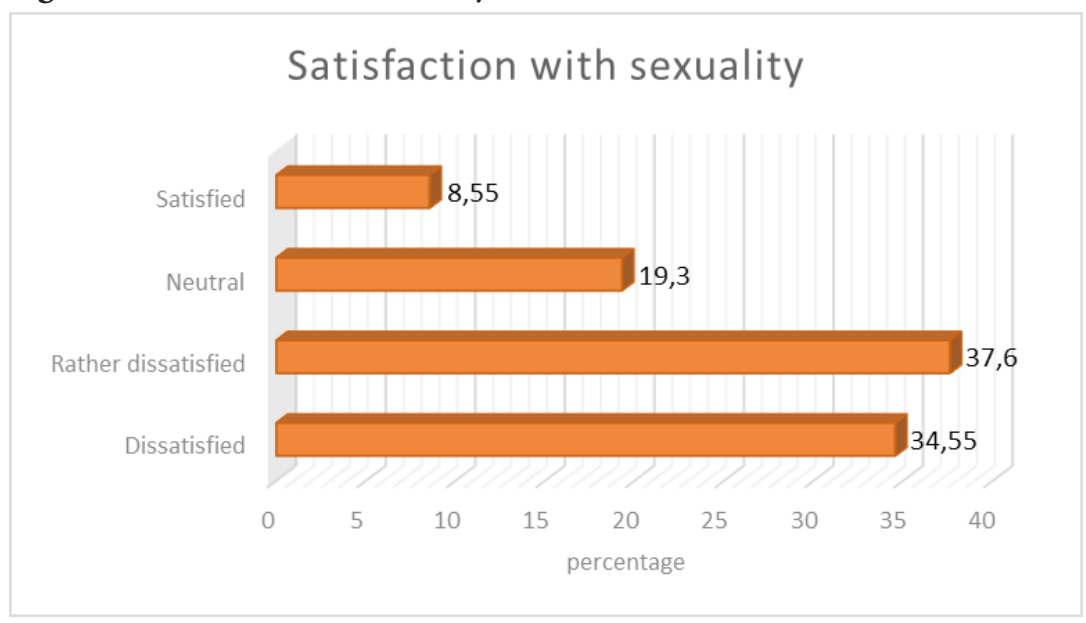


without feelings of guilt. The most dissatisfied with their sexuality, however, were not those who had conservative sexual ethics, but those who were undecided about this or who were located somewhere between conservative and liberal sexual ethics.

Due to the sampling strategy, there might be an over-representation of singles participating in online-dating-platforms $(n=968)$, which could influence the analysis of their satisfaction with e.g. sexuality. Or there might be a correlation between their participation access and their religiosity: it might be that participants who read Christian magazines $(n=443)$ (where the survey was advertised in) were more religious than participants who were drawn into the sample through other sampling-strategies.

\section{Conclusion}

The results clearly show a double deviation amongst 'highly religious' Protestant singles with regard to sexuality. On the one hand, they deviate from the liberalized sexual norms of society as a whole, and on the other hand, from the more or less conservative norms of their community environment. Accordingly, a clear majority of them cannot enjoy sexuality without feelings of guilt (2/3) and are dissatisfied with it (3/4). The more their sexual ethics deviate from their sexual practice, the more dissatisfied they are. Especially dissatisfied are those who cannot clearly decide between liberal and conservative sexual ethics. These could be the singles who, due to their character and the norms of their environment, perceive a deviation from biblical principles and guidelines in liberal sexual ethics, but perceive in themselves and others that these are not manageable. Conservative sexual ethics basically require a celibate life from Protestant-Christian singles, of whom only $4 \%$ feel called to be single, and also conceals how to live a good relationship with forms of sexuality that do not require a partner.

Our results confirm Engelberg's finding that most 'highly religious' Protestant singles do not adhere to the sexual-ethical norms of their highly religious context, but are significantly more conservative than the average population..$^{50}$ The tension resulting from the double deviation leads to greater dissatisfaction with one's own sexuality and probably implicates further negative feelings, such as guilt. The fact that such negative feelings towards oneself and towards God can lead to mental health problems has been shown by the research on relationships between religion/spirituality and mental health, which has intensified in recent years ${ }^{51}$ It can be assumed that there are many other highly religious singles - both within the Christian religion and in other religions - to whom similar patterns apply, not only in terms of double deviance but also in terms of the resulting dissatisfaction with one's own sexuality and other related consequences and problems. Further research would be needed here in order to investigate these connections more closely.

\footnotetext{
${ }^{50}$ Engelberg, "Update," 654.

${ }^{51}$ Hanneke Schaap-Jonker, "God Representations and Mental Health: Measurement, Multiplicity, and the Meaning of Religious Culture” (Ph.D. diss. Vrije Universiteit Amsterdam, 2018), 8.
} 
The results also confirm other findings of ideological dilemmas, which arise from a 'lived' ideology, these being "composed of the beliefs, values and practices of a given society or culture" and "are characterised by inconsistency, fragmentation and contradiction". ${ }^{52}$

Against the background of a holistic rather than reductionist understanding of sexuality, as is common in professional sex education, sexuality is associated with needs that involve more than orgasms and tension release, but rather more holistic needs for community, cohesion, touch, tenderness and being held. Our study also showed, however, that only a small minority (1/5) indicated that they had access to other possibilities or places to experience holistic physical closeness. ${ }^{53}$

Our study has also shown that the church and congregations do not help singles with this problem, but on the contrary often seem to aggravate it or even create it. ${ }^{54}$ The ProtestantChristian singles in this sample mostly have a high commitment and identification with their church. This is shown, for example, in the higher number of people who state they have a very good or good identification with their church (64\%). Nonetheless, there is a tension. Only one third stated that there was a regular exchange between singles and non-singles. 56 percent wanted singles to be included better in the church. The fact that there seemed to be a stigma surrounding being single in church is supported by the fact that only 30 percent agreed with the statement "It is completely normal to be single in my church". This could be due to the lack of special activities for singles, such as single-services or groups, which more than half of the singles wish for but only 6 percent report having as an option. Especially where sexuality was only considered legitimate within marriage, there were strong tendencies not to perceive or to suppress the sexuality of singles at all. This has many consequences for practical theology.

\footnotetext{
52 Jill Reynolds, Margaret Wetherell, and Stephanie Taylor, "Choice and Chance: Negotiating Agency in Narratives of Singleness," The Sociological Review 55, no. 2 (2007): 336.

${ }^{53}$ For a more detailed discussion, see Tobias Künkler, Tobias Faix and Johanna Weddigen, Christliche Singles: Wie sie leben, glauben und lieben (Holzgerlingen: SCM Verlagsgruppe, 2020), $132 \mathrm{f}$.

${ }^{54}$ Künkler et al., Christliche Singles, 128-132.
}

\section{Bibliography}

Addie, Elizabeth, and Brownlow, Charlotte. "Deficit and Asset Identity Constructions of Single Women without Children Living in Australia: An Analysis of Discourse." Feminism \& Psychology 24, (2014): 423-439. https://doi.org/10.1177/0959353514539463

Baas, Stephan, Schmitt, Marina, and Wahl, Hans-Werner. Singles im mittleren und höheren Erwachsenenalter, Sozial-wissenschaftliche und psychologische Befunde. Stuttgart: Kohlhammer, 2008.

Cargan, Leonard. Being Single on Noah's Ark. Lenham: Rowman \& Littlefield Publishers, 2007. 
Collett, Jessica L., and Lizardo, Omar. "A Power-control Theory of Gender and Religiosity." Journal for the Scientific Study of Religion 48, (2009): 213-231. https://doi.org/10.1111/j.1468-5906.2009.01441.x

Engelberg, Arie. "Update: Singles in Late-Modern Conservative Religions." Journal for the Scientific Study of Religion (ISSR) 55, no. 3 (2016): 652-655. https://doi.org/10.1111/jssr.12290

Gaynor, Pamela A., and Underwood, Julie K. “Conceptualizing and Measuring Sexual Self-esteem.” In Personality Research, Methods, and Theory, edited by P. E. Shrout and S. T. Fiske, 333-347. London: Erlbaum, 1995. https://doi.org/10.1111/10.4324/9781315806815-20

Häring, Armando, Klein, Thomas, Stauder, Johannes, ang Woll, Anke. "Partnermarkt und Suchverhalten von Singles in Deutschland." In Partnerschaft, Fertilität und intergene-rationale Beziehungen. Ergebnisse der ersten Welle des Beziehungs-und Familienpanels, edited by J. Brüderl, L. Castiglioni, and N. Schumann, 49-72. Würzburg: Eragon-Verlag, 2011.

Hertel, Janine, Schütz, Astrid, DePaulo, Bella M., Morris, Wendy L., and Stucke, Tanja S. "She’s Single, so what? How Are Singles Perceived Compared with People who are Married?” Zeitschrift für Familienforschung 19, no. 2 (2007). accessible online: http://nbn-resolving.de/urn:nbn:de:0168-ssoar-58080 [last accessed: 13.01.2020].

Hradil, Stefan. "Vom Leitbild zum „Leitbild“: Singles, ihre veränderte Wahrnehmung und der „Wandel des Wertewandels“.” Zeitschrift für Familienforschung 15, no. 1 (2003): 35-54. accessible online: http://nbnresolving.de/urn:nbn:de:0168-ssoar-282879 [last accessed: 13.01.2020].

Huber, Stefan. Zentralität und Inhalt: Ein neues multidimensionales Messmodell der Religiosität. Opladen: Leske und Budrich, 2003. https://doi.org/10.1007/978-3-663-11908-1

Huber, Stefan. "Are Religious Beliefs Relevant In Daily Life? In Religion Inside and Outside Traditional Institutions." In Empirical Studies in Theology 15, edited by Streib, Heinz, 209-230. Leiden and Boston: Brill, 2007. https://doi.org/10.1163/ej.9789004157927.i-322.64

Huber, Stefan. "Kerndimensionen, Zentralität und Inhalt. Ein Interdisziplinäres Modell der Religiosität." Journal für Psychologie 16, (2008). https://doi.org/10.7892/boris.73105

Huber, Stefan. "Religiosität in Deutschland, Österreich und der Schweiz." In Gesundheit-Religion-Spiritualität, edited by Klein, Constantin i.a., 163-188. Weinheim, 2011.

Huber, Stefan, and Huber, Odilo W. "The Centrality of Religiosity Scale (CRS)." Religions 3, (2012): 710-24. https://doi.org/10.3390/rel3030710

Huber, Stefan. "Hochreligiös gleich fundamentalistisch? Eine Einordnung." In Evangelisch Hochreligiöse im Diskurs, edited by Faix, Tobias i.a., 53-66. Stuttgart: Kohlhammer, 2020.

Jaeggi, Eva. Ich sag' mir selber Guten Morgen: Single-eine moderne Lebensform. München: Piper, 1992.

Kadasch, Christiane. Beziehungs-und Bindungspersönlichkeitstypen bei Singles. Marburg: Tectum, 2012.

Künkler, Tobias, Faix, Tobias, and Weddigen, Johanna. Christliche Singles: Wie sie leben, glauben und lieben. Holzgerlingen: SCM Verlagsgruppe, 2020.

Künkler, Tobias, Faix, Tobias, Weddigen, Johanna, Beckemeier, Daniel, Jäckel, Marie, Merz, Simon, and Funke, Philipp. "Forschungsbericht zur Empirica Singlestudie 2020: Lebensweisen christlicher Singles." (2020). accessible online: https://www.cvjm-hochschule.de/fileadmin/2_Dokumente/5_FORSCHUNG/ empirica/2020_Forschungsbericht_Singlestudie.pdf [last accessed: 28.09.2020].

Monyk, Elisabeth. Lieber alleine oder zu zweit? Die individualistische Lebensweise von Singles und kinderlosen Paaren. Münster, Berlin: LIT Verlag, 2007. 
Reese, Annegret. "Ich weiß nicht, wo da Religion anfängt und aufhört. Eine empirische Studie zum Zusammenhang von Lebenswelt und Religiosität bei Singlefrauen.” In Schriftenreihe: Religionspädagogik in pluraler Gesellschaft (RPG) 4, edited by Ziebertz, H.-G., Schweizer, F., Englert, R., and Schwab, U. Gütersloh: Gütersloher Verlagshaus, 2006. https://doi.org/10.5282/mthz/4439

Reynolds, Jill, Wetherell, Margaret, and Stephanie Taylor. "Choice and Chance: Negotiating Agency in Narratives of Singleness." The Sociological Review 55, (2007): 2. https://doi.org/10.1111/j.1467-954X.2007.00708.x

Schaap-Jonker, Hanneke. "God Representations and Mental Health: Measurement, Multiplicity, and the Meaning of Religious Culture.” Ph.D. diss., Vrije Universiteit Amsterdam, The Netherlands, 2018.

Single Friendly Church (2020) the Research, URL: https://www.singlefriendlychurch.com/research/research. [last accessed: 01.10.2020].

Sprenger, Robin. Männliche Absolute Beginner: Ein kommunikationswissenschaftlicher Ansatz zur Erklärung von Partnerlosigkeit. Wiesbaden: Springer Verlag, 2014. https://doi.org/10.1007/978-3-658-05924-8

Simpson, Roona. "Singleness and Self-identity: The Significance of Partnership Status in the Narratives of Never-married Women." Journal of Social and Personal Relationships (JSPR) 33, no. 3 (2016): 385-400. https://doi.org/10.1177/0265407515611884

Smith, Joy Beth. Party of One: Truth, Longing and the Subtle Art of Singleness. Nashville: Nelson Books, 2018.

Snell, William E. “The Multidimensional Sexual Self-Concept Questionnaire.” In Handbook of Sexualityrelated Measures, edited by C. M. Davis, W. L. Yarber, R. Bauserman, G. E. Schreer, and S. L. Davis. Newbury Park: Sage, 1998. https://doi.org/10.13140/RG.2.1.5057.1928

Strauss, Anselm, and Corbin, Juliet. Grounded Theory: Grundlagen Qualitativer Sozialforschung. Wiesbaden: VS Verlag für Sozialwissenschaften, 1996.

Tweed, Julie Michelle. "An Examination of Changing Perceptions of Singlehood.” Thesis in partial fulfilment of the requirements for the degree of Master of Arts in Sociology, Faculty of the Department of Sociology and Anthropology, East Tennessee State University, 2008.

Winter, Laraine. "The Role of Sexual Self-concept in the Use of Contraceptives." Family Planning Perspectives 20 (1988): 123-127. https://doi.org/10.2307/2135700

Wulf, Jean, Prentice, David, Hansum, Donna, Ferrar, Archie, and Spilka, Bernard. "Religiosity and Sexual Attitudes and Behavior among Evangelical Christian Singles." Review of Religious Research 26, (1984). https:// doi.org/10.2307/3511697 